\title{
Ethics in Employee Selection: What You Want to Know but are Afraid to Ask
}

\author{
Nhung T. Nguyen ${ }^{*}$ \\ Department of Management, College of Business \& Economics, Towson University, USA
}

Despite the fact that diversity management in the workplace has been regulated by equal employment opportunity legislation for decades, the topic of ethics in employee selection has not been widely examined. It can be argued that most managers' modus operandi considers what is legal the same as what is ethical. This narrow mindset coupled with the dominant utilitarian view in decision making may explain why corporate managers around the world are conflicted when it comes to making ethical hiring decisions. For example, according to a recent survey of college graduates with incomes in the top quarter of their occupational group, forty-three percent of British respondents, fifty-six percent of Americans and sixty percent of Swedes continue to agree with Milton Friedman's classic 1970 [1] assertion "the social responsibility of business is to increase its profit" [2]. Given such survey results, it is not surprising to see that in order to satisfy multiple corporate stakeholders, managers are prone to making decisions that may be legal (i.e., hiring based on merit), but not ethical (i.e., poaching talent from competitors, making it an unfair hiring practice).

Employee selection is an interesting area within which to view the role of ethics on decision making. Given the importance of making a good hiring decision, or avoiding making a false positive or false negative hiring decision, there are strong utilitarian considerations involved in most selection decisions. However, in this editorial, it is my argument that in addition to utilitarian criteria in making hiring decisions, the ethical sensitivity or awareness of fairness and rights should also be taken into account in order to achieve ethical hiring decisions.

Despite nearly fifty years of enforcement of equal employment opportunity laws in which hiring managers are prohibited to make hiring decisions based on non-job related factors (e.g., sex, race, religion, national origin, color, disability, and age), the effectiveness of diversity management programs (e.g., promoting women in traditionally male occupations) have had limited success [3]. On the other hand, hiring managers are still inconsistent in following ethical principles. For example, according to a recent survey published in the Wall Street Journal, executives in the financial and technology industries were the most aggressive when it comes to recruiting such as collecting competitive intelligence at a trade show whereas the government and pharmaceutical executives were more trepid of the same practice [4]. Respondents were asked to rate the appropriateness of recruitment practices as being "normal"; "aggressive", "unethical", or "illegal". Researchers reported that whereas the use of going undercover to gain information about recruiting practices at competing firms was considered "aggressive" by the government, most executives in the private sector viewed it as "unethical". Likewise, whereas viewed by the pharmaceutical and healthcare executives as unethical for an executive to mask his or her identity in order to gain intelligence of rival companies, it was viewed as merely an aggressive tactic but not unethical by executives in the financial and high tech firms [4].

Most studies in the ethics of employee selection focused on how firms enforced equal employment opportunity (EEO) laws. However, enforcement of EEO laws only reflects the extent to which employee selection is legal, not ethical. Unfortunately, codes of ethics have been found ineffective in promoting equal employment opportunities unless the codes of ethics were integrated into organizational daily decision making practice [5]. In employee selection, it is important to understand why among two otherwise equally qualified candidates, hiring managers decide to recommend hiring one over another when such a decision does not conform to ethics principles. It is possible that hiring managers lack consistency in following ethical principles [4] as well as moral sensitivity when making such hiring decisions. For example, in September 2009, the U.S. Department of Justice investigated six technology companies, namely Google, Intel, Intuit, Apple, Adobe, and Pixar for their allegedly covert agreement not to hire or "poach" one another's employees. According to the Department of Justice, this practice suppressed free market competition by holding down wages, and therefore was considered unfair. The six companies denied any wrongdoing, but decided to settle the case. Therefore, the question of whether "talent poaching" was illegal or not was never resolved because the investigation was discontinued and settled in September of 2010 before it went to court [6].

The practice of "poaching" talent from rival companies is not new and considered one of the fastest ways to gain competitive intelligence. Butterfield et al. [7] surveyed competitive intelligence practitioners using a hiring scenario and a mystery shopping scenario. Butterfield et al. [7] argued that a high degree of competition might blind managers to the moral sensitivity inherent in the hiring situation. In a recent study, upper undergraduate students were asked to play the role of a hiring manager with a choice of hiring an external male candidate who had worked for a rival company and was willing to sell out (hiring this candidate would conform to utilitarian ethics) and an external female candidate (hiring this candidate would conform to justice ethics). Both candidates were otherwise considered equally qualified. Students who chose to hire the external male candidate were found to have a lower level of moral/ethical sensitivity compared to those who chose to hire the external female candidate [8]. In another experimental study, Nguyen [9] found that among two equally qualified candidates, the male candidate is significantly more likely to be selected compared to the female candidate. The results of the above two studies indicate that despite decades of enforcing EEO laws, the impact of such laws on promoting women in the work place remains small. We as business educators may need to do a better job at sensitizing our students who will be future managers about the ethical implications in hiring

*Corresponding author: Nhung T. Nguyen, Associate professor, Department of Management, College of Business \& Economics, Towson University, USA, Tel: 410-7042900; Fax: 410-663-0207; E-mail: nnguyen@towson.edu

Received December 25, 2012; Accepted December 26, 2012; Published December 27, 2012

Citation: Nguyen NT (2013) Ethics in Employee Selection: What You Want to Know but are Afraid to Ask. J Bus \& Fin Aff 2:e124. doi:10.4172/2167-0234.1000e124

Copyright: (c) 2013 Nguyen NT. This is an open-access article distributed under the terms of the Creative Commons Attribution License, which permits unrestricted use, distribution, and reproduction in any medium, provided the original author and source are credited. 
Citation: Nguyen NT (2013) Ethics in Employee Selection: What You Want to Know but are Afraid to Ask. J Bus \& Fin Aff 2:e124. doi:10.4172/21670234.1000 e124

decisions. This means we need to raise the level of ethical awareness among our students because without ethical awareness, any effort in teaching ethical principles will be futile.

\section{References}

1. Friedman M (1970) The Social Responsibility Of Business Is To Increase Its Profits. The New York Times Magazine, September 13.

2. The Economist (2011) Attitudes to Business: Milton Friedman Goes on Tour. A Survey of Attitudes To Business Turns up Some Intriguing National Differences. January 27.

3. Falkenberg LE, Boland L (1997) Eliminating barriers to employment equity in the Candaian workplace. Journal of Business Ethics 16: 963-975.

4. Light J (2011) Finance and Tech Signal Bold Attitudes on Ethics. The Wall Street Journal, Career section, March 7.
5. Petersen LE, Krings F (2009) Are Ethical Codes of Conduct Toothless Tigers For Dealing With Employment Discrimination? Journal of Business Ethics 85: 501-514.

6. Catan T, Kendall B (2010) September 17. U.S. Tech Probe Nears End, Wall Street Journal (Eastern Edition), p. B.1. Retrieved January 4, 2011, from ProQuest National Newspapers Core.

7. Butterfield KD, Treviňo LK, Weaver GR (2000) Moral awareness in business organizations: Influence of issue-related and social context factors. Human Relations 53: 981-1018.

8. Nguyen NT, Basuray MT, Smith WP (2012) Ethics in employee selection: A case for improving awareness. Proceedings of the Institute of Higher Education-The 7th International Conference Williamsburg, VA-March 7-9.

9. Nguyen NT (2012) Gender Differences in Social Media Faux Pas in Personne Selection - An Empirical study. Paper presented at the 26th Annual Conference of the Australian and New Zealand Academy of Management, December 5th 7th Perth: Western Australia. 